\title{
Factors Associated With Inadequate Receipt of Components and Non-use of Antenatal Care Services in India: A Regional Analysis
}

Nilu Nagdev

Western Sydney University

Felix Akpojene Ogbo

Western Sydney University

\section{Mansi Dhami}

Western Sydney University

Thierno Diallo

Western Sydney University

David Lim

Western Sydney University

Kingsley Emwinyore Agho ( $\sim$ k.agho@westernsydney.edu.au )

Western Sydney University

\section{Research Article}

Keywords: antenatal care, women, India, demographic and health survey, maternal health

Posted Date: January 3rd, 2022

DOI: https://doi.org/10.21203/rs.3.rs-1138036/v1

License: (c) (i) This work is licensed under a Creative Commons Attribution 4.0 International License. Read Full License 


\section{Abstract}

Background

Failure to use antenatal care (ANC) and inadequate receipt of components of ANC pose a significant risk for both the pregnant woman and baby. This study aimed to examine a regional analysis of factors associated with no or inadequate receipt of components of ANC services among Indian women.

\section{Method}

Information on 184,628 women of reproductive age 15-49 years from the 2015-16 India National Family Health Survey (NFSH-4) was used. Survey multinomial logistic regression analyses that adjust for cluster and survey weights were conducted to assess the socio-demographic and other factors associated with no or receipt of inadequate receipt of components of ANC in the six regions in India.

Results

Across regions in India, $18 \%$ of women reported no ANC, and the prevalence of inadequate and adequate receipt of components of ANC in all six regions ranged from $16 \%$ to $43 \%$ and $34 \%$ to $81 \%$, respectively. Our analyses revealed that in all six regions, poor households reported increased odds of receiving no or inadequate receipts of components of ANC. In all six regions, inadequate receipts of components of ANC was significantly higher among women who had limited knowledge about pregnancy complications and post-delivery complications. In all the six regions except the East region, women who delivered their babies at home reported higher odds of receiving no or inadequate receipts of components of ANC and women who had no postnatal checkup after delivery reported higher odds of receiving no or inadequate receipts of components of ANC in all regions except South, West and North East regions. Low levels of women's education and women who delivered their babies at home were associated with increased odds of receiving no or inadequate receipts of components of ANC in all six regions except North and East regions.

\section{Conclusion}

A better understanding of the factors associated and incorporating them into the short- and long-term intervention strategies, including free financial support from the Indian government to encourage pregnant women from lower socioeconomic groups to use health services across all regions.

\section{Background}

Globally, 830 women die daily due to pregnancy- and childbirth-related complications [1]. Evidence from the Global Burden of Disease, Injuries and Risk Factors (GBD) study 2015 revealed that 75\% of these maternal deaths could be attributed to inadequate use of ANC services which may lead to pregnancy complications or childbirth in many low and middle-income countries (LMICs) including South Asia countries [2]. According to the World Health Organization (WHO), adequate receipt of antenatal care consists of 4 or more antenatal visits and the receipt of 7 or more ANC components [3]. The components of adequate ANC included: confirming the pregnancy date and expected time of delivery; obstetric examination and blood pressure check; urine and blood test; treatment of diseases if required; tetanus toxoid vaccination; iron and folate supplementation; and health education on self-care, nutrition and sleeping under insecticide-treated bed-nets [4, 5]. Failure to use antenatal care (ANC) and inadequate receipt of antenatal care (ANC) services utilisation can have adverse health effects for both mother and baby during pregnancy and childbirth, including reducing the risk of stillbirths and pregnancy complications and giving women a positive pregnancy experience [6]. 
The global burden of maternal and neonatal mortality due to inadequate receipt of ANC services could be reduced with the effective implementation of health education and health promotion strategies [3], including routine health checkups during pregnancy. India is one of the South Asian countries with the highest maternal deaths (214-300 maternal deaths per 100000 live births), which makes the country lie well behind the Sustainable Development Goals (SDGs-3) of reducing maternal mortality ratio to less than 70 maternal deaths per 100,000 live births by $2030[1,7]$. To better inform maternal policies and programmes focused on reducing MMR in India, detailed information on key determinants of inadequate receipt of the components and non-use of antenatal care services will be required.

Evidence from a systematic review from nine studies published between 2000 and 2017 that examined the effectiveness of programmes related to adequate receipt of services, including the consumption of iron-folic acid (IFA) supplements in South Asian countries, revealed that mother's with no schooling, lowest wealth index quartile, lack of family support to women access to services, lack of quality counselling, an inadequate supply of supplements are all barriers affecting inadequate receipt of services during pregnancy in South Asian countries [8]. Similarly, evidence from studies conducted in Nepal [9], Bangladesh [6] and Pakistan [10] indicated that household wealth, education and living in urban areas were associated with the receipt of ANC components. Early supplementation intake, four or more ANC visits during pregnancy, and free IFA supplements are factors associated with adequate receipt of ANC components [11-13].

Some regional studies focused on a few ANC components and non-use of ANC visits in India. A study conducted in Uttar Pradesh that focused on the compliance to ANC visits and the tetanus toxoid (TT) vaccination coverage indicated that Upper caste women were significantly more likely to use the combination of ANC, tetanus toxoid and contraceptives than lower caste women [14]. In northern India, another study focused on three ANC components (TT vaccination, blood and urine test) indicated that higher social and economic status was strongly associated with increased odds of receiving ANC components [15]. Similarly, a study conducted in Bihar showed that about $37 \%$ of pregnant women received IFA supplements and attended 4 or more ANC during pregnancy [16]. The study also found a strong interaction between ANC quality and the quality of counselling [16]. In addition, a study conducted on the quality of antenatal care in four south Indian states found that women from disadvantaged socioeconomic households were significantly associated with the quality of care [17].

Past studies that have focused on receipt of ANC components across regional India are limited by the fact that they are not population-based studies and may not be generalizable to the wider Indian population and the studies that did not examine the receipt of all ANC components. Investigating the number of ANC visits and the receipt of ANC components during pregnancy are important factors for reducing maternal and neonatal mortality across Indian regions. Reports from India have revealed wide variations in education, health, sociocultural, religious and economic indicators among women across regional India, with the potential effect on maternal health-seeking behaviour and use of health facilities during pregnancy. Also, a recent nationwide study in India suggested that region-specific assessment of the determining factors of ANC service uptake is needed to guide a more equitable distribution of maternal health resources and programmes [18] as national level evidence can conceal subnational variations. The main aim of this study was to determine a regional analysis of factors associated with no ANC visits and inadequate receipt of ANC in India. This study's findings would help policymakers develop new health interventions and allocations targeting women of childbearing age in these regions in India with low compliance to full receipt of ANC components.

\section{Methods}

National Family_Health Survey_( 
We extracted information from 2015-16 Demographic Health Surveys (DHS) data is also known as the National Family Health Survey (NFSH-4) surveys done and these survey datasets are availability from the DHS website (as they are needed for secondary data analyses).

\section{Data source}

The NFSH-4, a population-based India survey, collected by the Ministry of Health, with technical assistance provided by the Inner-City Fund (ICF) International will be used in this study. The representative sample consisted of pregnant women aged 15-49 years [19]. Two-stage sampling was used to retrieve the data in both rural and urban areas. In the first stage, the village units were designated as Primary Sampling Units (PSU), and the urban units were designated as Census Enumeration blocks in which households were sampled. Across India, nearly 572,000 households were selected, which yielded more than a 95\% response rate[19].

Our analyses were restricted to the singleton live-birth infants of the women' most recent birth within the five years preceding the survey, which yielded a weighted total of 150,093 women. Furthermore, our restriction aimed to reduce recall bias of women about their previous pregnancies.

\section{Outcome variables}

This study considered two outcome variables. These are the frequency of antenatal care (ANC) visits, and the second outcome relates to receiving the recommended essential receipts of ANC components during pregnancy. In the second outcome variable, we created a composite score of receipts of ANC components which comprises a simple count of the receipts of ANC components a pregnant mother received in her most recent birth within the five years prior to the survey. The second outcome variable had a minimum value of zero, indicating that a pregnant mother did not receive ANC services and a maximum value of nine, indicating that the women received services for all the nine receipts of ANC components. The outcome variables for this study were divided into 3 categories: 1) Adequate receipt of ANC components, 2) inadequate receipt of ANC components and, 3) No ANC visit. In our analysis, adequate receipt of ANC components was assigned ' 1 ', inadequate receipt of ANC components was categorised as ' 2 ' and while, and no ANC was assigned ' 3 '. No ANC visit category included infants whose women never attended ANC visits during pregnancy. Inadequate receipt of ANC components are infants whose women reported less than the four ANC visits during pregnancy and used less than 9 receipts of ANC components and, adequate receipt of ANC components are infants whose women attended four or more ANC visits during pregnancy and used all the 9 receipts of ANC components.

According to the $\mathrm{WHO}$, appropriate components of ANC included: confirming the pregnancy date and expected time of delivery; obstetric examination and blood pressure check; urine and blood test; treatment of diseases if required; tetanus toxoid vaccination; iron and folate supplementation; and health education on self-care, nutrition and sleeping under insecticide-treated bed-nets $[4,5]$. However, in the present study, nine components were used based on NFSH-4. Those components included: told about pregnancy complications, had abdomen examined, weight measured during pregnancy, given iron/folic acid supplementation, given the drug for intestinal parasites, had tetanus injection before birth, blood pressure check, urine and blood test during pregnancy.

\section{Study variables}

We modified the behavioural model framework of Andersen [20] to group the factors potentially associated with inadequate receipt of ANC components (Figure 1). Twenty-five potential risk factors were identified and categorised into four main groups, community-level factors, predisposing (socio-demographic and health knowledge), enabling including health services and need factors. 


\section{Statistical analysis}

Data analysis was performed using the survey "svy" commands of Stata version 13.1 (Stata Corp, College Station, TX, USA), which allowed for adjustments for sampling weights. The Taylor series linearization method was used to estimate confidence intervals (Cls) around prevalence estimates in the surveys. First, regional frequency tabulations were conducted to describe the data used in this study, followed by the Taylor series linearization method in the surveys when estimating 95\% confidence intervals around the regional prevalence of no ANC, inadequate and adequate receipt of components of ANC. Multinomial survey logistic regression models that adjusted for clustering and sampling weights were used to identify factors with no or inadequate receipt of components of ANC.

As part of the multivariable analysis, a five-stage model was performed by following a similar conceptual model approach to that employed by Andersen [20]. In the first modelling stage, community and socioeconomic factors were first entered into the model to assess their associations with the study outcomes. A manually executed backward elimination method was conducted to select factors significantly associated with the outcomes. In the second model, the significant factors in the first stage were added to health knowledge factors, and a manually executed backward elimination procedure followed this. A similar approach was used for enabling health services and need factors in the third, fourth and fifth stages, respectively. To avoid any statistical bias, we double-checked our manually executed backward elimination method by using the following procedures: (1) we entered only potential risk factors with P-value $<0.20$ in the backward elimination process, (2) we tested the backward elimination by also including all variables (all potential risk factors); and, (3) we tested and reported any collinearity in the final model. The odds ratio (OR) with $95 \%$ Cls were calculated in order to assess the adjusted risk of independent variables, and those with $\mathrm{P}<0.05$ were retained in the final model.

\section{Results}

\section{Regional characteristics of the study participants}

Table 1 reported the regional characteristics of the study population, and as across all regions in India, more than twothirds of women were aged between 20 and 39 years. As summarized in table 1, above $50 \%$ of women in the North, South and West regions were classified as rich, while above $50 \%$ of women from East, Central and North Eastern regions were poor. Across all the six regions, less than $3 \%$ of women were either divorced, separated, or widowed across all the six regions. More than $78 \%$ of women across all regions delivered their babies in the health facility, with the highest percentage in the South region (95.9\%) and the lowest in the North-Eastern region (71.1\%). Across all the six regions, more than $80 \%$ of women reported that their husband has power over money earned and make power over household purchasing decision making.

\section{Regional prevalence of receipt of components of ANC visits}

Table 2 revealed the regional prevalence receipt of components of ANC visits received by Indian women during last pregnancy and according to the table, above $90 \%$ of women who lived in North, South and West regions had abdomen examined, weight measured, blood pressure check, urine and blood test during pregnancy. About $70 \%$ of women received iron/folic supplementation across all regions in India.

Pregnant women given intestinal parasites drugs lie between $8 \%$ and $32 \%$, with the South region contributing the most (32.1\% of the study sample) and North Eastern contributing the least (8.4\%). Nationally, all the components of ANC were suboptimal except weighed during pregnancy. 


\section{Regional prevalence of no, inadequate and adequate receipts of components of ANC}

Figure 2 showed the regional prevalence and $95 \%$ confidence intervals of no ANC, inadequate receipts, and adequate receipts of ANC components in India. According to figure 2, the prevalence of no ANC was significantly higher in the East and Central region and lowered in the South region.

The central region had a significantly higher prevalence of inadequate receipt of ANC components. In contrast, the prevalence of inadequate receipt of ANC components did not differ statistically (because the confidence interval bars crosses each other) in the East and Central region. South and West regions reported the highest prevalence of adequate receipt of ANC components, while the Central region reported the lowest (see Figure 2).

\section{Factors associated with no ANC}

The odds of no ANC visits were significantly lower among women who delivered at health facilities located in all the six regions except the East region of India. No ANC visit was significantly lower among women who had secondary or more levels of education and women told about delivery complications and post-delivery complications in all regions except the East region. Women from rich households in West and North East regions significantly reported lower odds of no ANC visit [Table 3].

Women who received ANC at Private Health Centre reported lower odds of no ANC in all regions except the West region. Similarly, the odds of no ANC visit were significantly higher among women who reported that permission to visit health services was not a big problem in the West and East regions. Women who reported that money to pay for health services was a big problem were significantly more likely to make no ANC visit in the North region.

Women who had never listened to the radio and those who never watched television were significant factors associated with increased odds of receiving no ANC visit in North (AOR $=3.07 ; 95 \% \mathrm{Cl}: 1.95$ to 4.85$)$ and East regions ( $A O R=1.49 ; 95 \% \mathrm{Cl}: 1.01$ to 2.22 ), respectively. Women autonomy over finances and older women (30 years or more) reported lower odds of receiving no ANC in the North region, respectively.

\section{Factors associated with inadequate receipt of ANC components}

As shown in Table 4, the receipt of inadequate components of ANC was significantly higher among women that lived in Central region rural areas of India. The receipt of inadequate components of ANC was significantly lower among women who delivered at health facilities located in all regions except the East region. In all regions, the odds of inadequate components of ANC were significantly lower among women from rich households. Women who had secondary or more levels of education reported lower odds of inadequate components of ANC in all regions except the West region.

First time women were significantly less likely to report inadequate components of ANC in all regions except West and South regions compared with women who had 2 nd or 3 rd birth rank infants with a short birth interval of less than or equal to two years. In all regions, the receipt of inadequate components of ANC was significantly higher among women who had limited knowledge about pregnancy complications and those with limited knowledge about postdelivery complications.

The odds of receiving inadequate components of ANC were significantly higher among women who reported that money to pay for health services was a big problem in all regions except the East and West regions. Similarly, women who reported that permission to visit health services was a big problem were significantly more likely to report inadequate components of ANC in the South, East, West, and North Eastern regions. Women autonomy over finances 
and mothers who reported no domestic violence reported lower odds of inadequate components of ANC in North and East regions, respectively.

Compared with women who used a contraceptive, women who did not know about contraceptives were significantly more likely to report inadequate components of ANC in all 6 regions except the South region. Women who had no postnatal checkup after delivery reported higher odds of inadequate components of ANC in all regions except West and North East regions; conversely, women who had limited knowledge about contraceptive use were significantly more likely to report inadequate components of ANC in all regions except the south region. The odds of inadequate components of ANC in North, Central and North East were significantly higher in women who no longer wanted pregnancy than in women who wanted pregnancy now by $35 \%, 39 \%$ and $70 \%$, respectively.

\section{Discussion}

\section{Main findings}

The components of ANC received by Indian women varied in the present study. Less than one in five (18\%) Indian women reported no ANC visit during pregnancy, and about a third of Indian women reported inadequate receipts of ANC components. In this regional analysis, several factors have emerged that explain the inadequate receipt of ANC components and no ANC in India. Women who reported limited knowledge about delivery complications, women from rich households, women who delivered at the health facility, women who reported big problems with money to pay for health services were associated with no ANC visit and inadequate receipts of components of ANC in almost all the regions in India.

A recent study revealed that pregnant women in low and middle-income countries do not have access to all ANC components recommended by WHO [21]. This study found that the prevalence of inadequate receipt of ANC components and No ANC were relatively lower $(<20 \%)$ in South and East regions than the Indian national average. This study observed that blood pressure check, weight check during pregnancy blood and urine sample collected for investigation was relatively high (> 80\%) in all regions except the Central region. However, drugs for intestinal parasites during pregnancy were low in all six Indian regions. These findings are consistent with district-level studies conducted in India for ANC visits, TT and IFA, where the results showed that more emphasis has to be given to the provision of ANC components [15].

\section{Factors associated with inadequate receipt of ANC components}

Our study found that residing in rural areas was associated with inadequate ANC components in the Central region. This result was consistent with the findings of other studies conducted in developing countries [11, 22, 23]. A possible cause of inadequate receipt of ANC components in the rural Central region of India could be attributed to little or no access to media, low level of education, less availability of health facilities and skilled health personnel and cultural methods adopted in pregnancy [15]. This finding could also relate to the fact that major health centres and hospitals in India are also located in urban areas, making rural pregnant women prefer receiving ANC components at home [24].

We found that women who reported limited knowledge about delivery complications and post-delivery complications had higher odds of inadequate receipt of ANC components in all 6 regions. These findings mirrored a recent study from India, which indicated that less than half of the pregnant women did not receive the minimum recommended 4 ANC visits [25]. A possible reason for this higher odds could be attributed to distance to health facilities and limited knowledge about delivery and post-delivery complications [26], and women may prefer not to deliver at the hospital due to the low quality of health facilities [27]. 
Thus, preference for home delivery among pregnant Indian women could be due to traditional cultural beliefs, the financial condition of the family to pay for health services and transport to the health facility, previous uncomplicated home deliveries, fear of medical procedures and obstetric examination [21, 23]. Also, insufficient access to media such as radio, magazines, television could be linked to poor maternal awareness about ANC services. Overcoming these barriers to inadequate receipt of ANC components by taking considerate actions at individual and community levels would enable the Indian government to achieve Sustainable Development Goals 3 of ensuring good health and promoting wellbeing at all ages. In addition, various programmes such as the free distribution of IFA supplements, free distribution of drugs for intestinal parasites should be integrated with ANC to improve the quality of ANC components provided at the rural level [23].

In this present study, women with no schooling and from poor household wealth reported a higher likelihood of inadequate receipt of ANC components than those from rich households and Secondary or more levels of education in all 6 regions. These findings supported that women in low socioeconomic groups have limited knowledge about ANC visits and ANC components, delivery and post-delivery complications, postnatal checkups or family planning $[25,26]$. These findings are also consistent with other studies from low-and middle-income countries such as Nepal [9], Pakistan [12, 28] and Nigeria [22], which highlighted that low maternal education levels and poorest households are associated with inadequate receipt of ANC components. Our findings imply that the Indian government should educate women on how to improve their health outcomes, especially during pregnancy and provide for free ANC services, including ANC components for women from a low socioeconomic group, in order to impact the quality of ANC components provided significantly and the use of ANC services will improve in low socioeconomic pregnant women especially rural women.

\section{Factors associated with no ANC}

We found that women with no education and poor households were more likely to not utilise ANC services in all regions except the West region. This finding is similar to other studies conducted in developing countries where low maternal education was one of the factors for no ANC visits $[12,22,29]$. A recent population-based study conducted in India in 2019 for enablers and barriers of ANC services also revealed that maternal education is associated with several ANC visits reported by pregnant women [18].

Our study showed that women who delivered their babies at home were more likely not to use ANC services in all regions except the East region than women who delivered their babies at the health facility and the East region marks relatively slow progress with $28 \%$ percent still delivered at home. This study supports a study that examined the relationship between quality of antenatal care and utilisation of health care delivery systems, and the study found that women who had more than three ANC visits reported a 7\% higher probability of having health facility than their counterparts who delivered at home with limited ANC visits [30]. However, empowering Indian women through education would promote a better understanding of health messages, including enabling pregnant women to choose institutional delivery, better decision-making capacity in the household and knowledge about delivery and post-delivery complications [26].

Women receiving ANC at private health centres correlates strongly with lower odds of no ANC in all regions, excluding the West region. This finding supported a systematic review that compared the performance of private and public sector delivery in low- and middle-income countries and found that service from government health centres lacks timeliness delivery of services, equipment, medications, and trained healthcare workers than a private health centre. Additionally, the government health centre is not well-funded and would violate medical standards of practice by providing poorer patient outcomes, including delivery services to pregnant women [31]. The big problem of paying money for the ANC services by pregnant women and the big problem with distance to health facilities were related to 
limited ANC visits. This finding was consistent with research conducted in Nepal [9], Pakistan [12, 28] and Nigeria [22],], which found that long distances to health facilities and access to ANC services were associated with No ANC visits. To improve adequate receipt of ANC components among pregnant women who visit government health centres, the Indian government should ensure that government health centres are well funded. Clinicians who work in the government health sectors should adhere to clinical guidelines through continuing medical education and promotion of health strategies to strengthen better health care for pregnant women, including monitoring and preventing poor quality health care.

Limitations of this study were due to the cross-sectional design, which does not allow causal association between the study factors and outcome variables. Also, as ANC components were self-reported by pregnant women, recall bias, misclassification, and measurement of factors associated with no or inadequate receipt of ANC components. However, the major strengths of this study are that it utilised the most recent DHS, which provide a population-based, nationally representative sample and cover large sample sizes with a $98 \%$ response rate. The study has good internal validity as the questionnaire was validated by trained health personnel.

This study highlights the factors associated with no or inadequate receipt of ANC components at the regional level in India. Poor households, knowledge about delivery complications and post-delivery complications were significant factors associated with increased risk of receiving no or inadequate quality ANC in all 6 regions in India. Home delivery reported higher odds of no ANC or inadequate quality ANC in all the 6 regions except the East region. Women who had no postnatal checkups after delivery, low mother's education level, and a big problem with paying for health services reported higher odds of no ANC or inadequate quality ANC in all the 6 regions in India except the West region. To improve women's access to ANC services across all regions in India, it is prudent to consider the factors mentioned above to monitor and improve the maternal health programme in India, including media campaigns for creating awareness about ANC services, especially among pregnant women from lower socioeconomic groups.

\section{Abbreviations}

ANC: Antenatal care; NDHS: Nigeria Demographic and Health Survey; WHO: World Health Organization; NFHS: National Family Health Survey; GBD: Global Burden of Disease; TT: Tetanus Toxoid vaccination; IFA: iron-folic acid; SDGs: Sustainable Development Goals; LMIC: Iow and middle-income countries; AOR: Adjusted Odds ratio; Cl: Confidence interval.

\section{Declarations}

\section{Ethics approval and consent to participate:}

The research design, including the content of all the survey questionnaires of the NFHS-4, was reviewed by the United States Centers for Disease Control and Prevention (CDC) and approved by both the ICF Institutional Review Board and the International Institute for Population Sciences (IIPS) Institutional Review Board. We obtained approval from Measure DHS to download and use the data for this study. All methods (use of data) were performed in compliance with the Declarations of Helsinki. The data used in our study, all identifier information removed, and no personal identity was compromised.

\section{Consent for publication:}

Not applicable 
Availability of data and materials:

The dataset analyzed during the current study are available in the DHS Program repository, https://dhsprogram.com/.

\section{Competing interests:}

The authors declare that they have no competing interests.

\section{Funding:}

This research received no specific grant from any funding agency in public, commercial or not-for-profit sectors.

\section{Authors' contributions:}

$\mathrm{NN}$ and KEA were involved in the conception and design of this study. NN carried out the analysis and drafted the manuscript. KEA, FAO, MD, DL and TD gave advice on interpretation and revised and edited the manuscript. All authors read and approved the final manuscript.

\section{Acknowledgements:}

This study is part of the first author Master of Public Health dissertation with the School of Health Sciences at Western Sydney University, Australia. We are grateful to Measure DHS, ORC Macro, Calverton, MD, USA for providing the 2017 National Family Health Survey (HFHS-4) data for this analysis.

\section{Authors Information (optional):}

\$GloMACH members are Kingsley E. Agho, Felix Akpojene Ogbo, Thierno Diallo, Osita E Ezeh, Osuagwu L Uchechukwu, Pramesh R. Ghimire, Blessing Jaka Akombi, Pascal Ogeleka, Tanvir Abir, Abukari I. Issaka, Kedir Yimam Ahmed, Daarwin Subramanee, Nilu Nagdev and Mansi Dhami.

\section{References}

1. Kassebaum NJ, Barber RM, Bhutta ZA, Dandona L, Gething PW, Hay SI, et al. Global, regional, and national levels of maternal mortality, 1990-2015: a systematic analysis for the Global Burden of Disease Study 2015. The Lancet. 2016;388(10053):1775-812.

2. World Health Organisation. World health statistics 20102010 [cited 2021 2/12/2021]. Available from: https://apps.who.int/iris/handle/10665/44292.

3. Organisation WH. WHO recommendations on antenatal care for a positive pregnancy experience 2016 [cited 2021 2/12/2021]. Available from: https://www.who.int/publications/i/item/9789241549912.

4. World Health Organisation. Women and health : today's evidence tomorrow's agenda 2009 [cited 2021 2/12/2021]. Available from: https://apps.who.int/iris/handle/10665/44168.

5. World Health Organisation. Maternal mortality 2021 [cited 2021 2/12/2021]. Available from: https://www.who.int/news-room/fact-sheets/detail/maternal-mortality.

6. Islam MM, Masud MS. Determinants of frequency and contents of antenatal care visits in Bangladesh: Assessing the extent of compliance with the WHO recommendations. PloS one. 2018;13(9):e0204752. 
7. Coffey D. Costs and consequences of a cash transfer for hospital births in a rural district of Uttar Pradesh, India. Social science \& medicine. 2014;114:89-96.

8. Goudet S, Murira Z, Torlesse H, Hatchard J, Busch-Hallen J. Effectiveness of programme approaches to improve the coverage of maternal nutrition interventions in South Asia. Maternal \& child nutrition. 2018;14:e12699.

9. Joshi C, Torvaldsen S, Hodgson R, Hayen A. Factors associated with the use and quality of antenatal care in Nepal: a population-based study using the demographic and health survey data. BMC pregnancy and childbirth. 2014;14(1):1-11.

10. Agha S, Tappis $\mathrm{H}$. The timing of antenatal care initiation and the content of care in Sindh, Pakistan. BMC pregnancy and childbirth. 2016;16(1):1-9.

11. Nguyen PH, Sanghvi T, Kim SS, Tran LM, Afsana K, Mahmud Z, et al. Factors influencing maternal nutrition practices in a large scale maternal, newborn and child health program in Bangladesh. PloS one. 2017;12(7):e0179873.

12. Nisar YB, Dibley MJ, Mir AM. Factors associated with non-use of antenatal iron and folic acid supplements among Pakistani women: a cross-sectional household survey. BMC pregnancy and childbirth. 2014;14(1):1-12.

13. Sharma S, Teijlingen Ev, Belizán JM, Hundley V, Simkhada P, Sicuri E. Measuring What Works: An impact evaluation of women's groups on maternal health uptake in rural Nepal. PloS one. 2016;11(5):e0155144.

14. Saroha E, Altarac M, Sibley LM. Caste and maternal health care service use among rural Hindu women in Maitha, Uttar Pradesh, India. Journal of midwifery \& women's health. 2008;53(5):e41-e7.

15. Pallikadavath S, Foss M, Stones RW. Antenatal care: provision and inequality in rural north India. Social science \& medicine. 2004;59(6):1147-58.

16. Wendt A, Stephenson R, Young M, Webb-Girard A, Hogue C, Ramakrishnan U, et al. Individual and facility-level determinants of iron and folic acid receipt and adequate consumption among pregnant women in rural Bihar, India. PloS one. 2015;10(3):e0120404.

17. Rani M, Bonu S, Harvey S. Differentials in the quality of antenatal care in India. International journal for quality in health care. 2008;20(1):62-71.

18. Ogbo FA, Dhami MV, Ude EM, Senanayake P, Osuagwu UL, Awosemo AO, et al. Enablers and barriers to the utilization of antenatal care services in India. International journal of environmental research and public health. 2019;16(17):3152.

19. International Institute for Population Sciences (IIPS), ICF. National Family Health Survey (NFHS-4)-National Report, Mumbai, India IIPS. 2017. Available from: http://rchiips.org/NFHS/NFHS-4Reports/India.pdf.

20. Andersen RM. Revisiting the behavioral model and access to medical care: does it matter? Journal of health and social behavior. 1995:1-10.

21. lyengar SD, lyengar K, Suhalka V, Agarwal K. Comparison of domiciliary and institutional delivery-care practices in rural Rajasthan, India. Journal of health, population, and nutrition. 2009;27(2):303.

22. Agho KE, Ezeh OK, Ogbo FA, Enoma Al, Raynes-Greenow C. Factors associated with inadequate receipt of components and use of antenatal care services in Nigeria: a population-based study. International health.

Page $11 / 28$ 
2018;10(3):172-81.

23. Bruce SG, Blanchard AK, Gurav K, Roy A, Jayanna K, Mohan HL, et al. Preferences for infant delivery site among pregnant women and new mothers in Northern Karnataka, India. BMC pregnancy and childbirth. 2015;15(1):110.

24. Gorain A, Barik A, Chowdhury A, Rai RK. Preference in place of delivery among rural Indian women. PloS One. 2017;12(12):e0190117.

25. Kumar G, Choudhary TS, Srivastava A, Upadhyay RP, Taneja S, Bahl R, et al. Utilisation, equity and determinants of full antenatal care in India: analysis from the National Family Health Survey 4. BMC pregnancy and childbirth. 2019;19(1):1-9.

26. Patel R, Marbaniang SP, Srivastava S, Kumar P, Chauhan S. Why Women Choose to Delivery at Home in India: A Study of Prevalence, Factors, and Socioeconomic Inequality. 2021.

27. Das J, Hammer J. Are institutional births institutionalizing deaths 2014 [cited 2021 3/12/2021]. Available from: https://www.worldbank.org/en/webarchives/archive?

url=https\%3A\%2F\%2Fweb.worldbank.org\%2Farchive\%2Fwebsite01605\%2FWEB\%2FARE_INST.HTM\&mdk=384273014.

28. Noh J-W, Kim Y-m, Lee LJ, Akram N, Shahid F, Kwon YD, et al. Factors associated with the use of antenatal care in Sindh province, Pakistan: A population-based study. PloS one. 2019;14(4):e0213987.

29. Shahjahan M, Chowdhury HA, Akter J, Afroz A, Rahman MM, Hafez M. Factors associated with use of antenatal care services in a rural area of Bangladesh. South-East Asia Journal of Public Health. 2012;2(2):61-6.

30. Dixit P, Khan J, Dwivedi LK, Gupta A. Dimensions of antenatal care service and the alacrity of mothers towards institutional delivery in South and South-East Asia. PloS one. 2017;12(7):e0181793.

31. Basu S, Andrews J, Kishore S, Panjabi R, Stuckler D. Comparative performance of private and public healthcare systems in low-and middle-income countries: a systematic review. PLoS medicine. 2012;9(6):e1001244.

\section{Tables}

Table 1: Characteristics of the study population by region in India, 2015-16 National Family and Health Survey 


\begin{tabular}{|lllllll|}
\hline Characteristic & $\begin{array}{l}\text { North } \\
(\mathrm{n}=22856)\end{array}$ & $\begin{array}{l}\text { South } \\
(\mathrm{n}=34573)\end{array}$ & $\begin{array}{l}\text { East } \\
(\mathrm{n}=46946)\end{array}$ & $\begin{array}{l}\text { West } \\
(\mathrm{n}=24240)\end{array}$ & $\begin{array}{l}\text { Central } \\
(\mathrm{n}=48848)\end{array}$ & $\begin{array}{l}\text { North Eastern } \\
(\mathrm{n}=7165)\end{array}$ \\
\cline { 2 - 3 } & $\mathrm{n}(\%)$ & $\mathrm{n}(\%)$ & $\mathrm{n}(\%)$ & $\mathrm{n}(\%)$ & $\mathrm{n}(\%)$ \\
\hline
\end{tabular}

\section{Community Level Factor}

\section{Type of place of residence}

\begin{tabular}{lllllll}
\hline Urban & $\begin{array}{l}8190 \\
(35.8)\end{array}$ & $\begin{array}{l}14905 \\
(43.1)\end{array}$ & $\begin{array}{l}8368 \\
(17.8)\end{array}$ & $\begin{array}{l}10787 \\
(44.5)\end{array}$ & $\begin{array}{l}11497 \\
(23.5)\end{array}$ & $1116(15.5)$ \\
\multirow{2}{*}{ Rural } & $\begin{array}{l}14665 \\
(64.1)\end{array}$ & $\begin{array}{l}19668 \\
(56.8)\end{array}$ & $\begin{array}{l}38578 \\
(82.1)\end{array}$ & $\begin{array}{l}13453 \\
(55.5)\end{array}$ & $\begin{array}{l}37351 \\
(76.5)\end{array}$ & $6048(84.4)$ \\
& & & & &
\end{tabular}

\section{Predisposing factors}

\section{Socio-demographic factors}

\section{Maternal age at child's birth (Years)}

\begin{tabular}{|c|c|c|c|c|c|c|}
\hline$<20$ & $1796(7.8)$ & $\begin{array}{l}3771 \\
(10.9)\end{array}$ & $\begin{array}{l}7637 \\
(16.2)\end{array}$ & $\begin{array}{l}2644 \\
(10.9)\end{array}$ & 3575 (7.3) & $1084(15.1)$ \\
\hline $20-29$ & $\begin{array}{l}17306 \\
(75.7)\end{array}$ & $\begin{array}{l}26939 \\
(77.9)\end{array}$ & $\begin{array}{l}32003 \\
(68.1)\end{array}$ & $\begin{array}{l}18425 \\
(76.0)\end{array}$ & $\begin{array}{l}35931 \\
(73.5)\end{array}$ & $4477(62.4)$ \\
\hline $30-39$ & $\begin{array}{l}3518 \\
(15.3)\end{array}$ & $\begin{array}{l}3759 \\
(10.8)\end{array}$ & $\begin{array}{l}6722 \\
(14.3)\end{array}$ & $\begin{array}{l}3072 \\
(12.6)\end{array}$ & $\begin{array}{l}8618 \\
(17.6)\end{array}$ & $1473(20.5)$ \\
\hline $40+$ & $236(1)$ & $105(0.3)$ & $584(1.2)$ & $100(0.4)$ & $724(1.4)$ & $131(1.8)$ \\
\hline \multicolumn{7}{|c|}{ Place of delivery } \\
\hline Home & $\begin{array}{l}3146 \\
(13.7)\end{array}$ & $1414(4.0)$ & $\begin{array}{l}13032 \\
(27.7)\end{array}$ & 2170 (8.9) & $\begin{array}{l}13032 \\
(26.6)\end{array}$ & $2064(28.8)$ \\
\hline Health facility & $\begin{array}{l}19710 \\
(86.2)\end{array}$ & $\begin{array}{l}33159 \\
(95.9)\end{array}$ & $\begin{array}{l}33915 \\
(72.2)\end{array}$ & $\begin{array}{l}22069 \\
(91.0)\end{array}$ & $\begin{array}{l}35816 \\
(73.4)\end{array}$ & $5101(71.1)$ \\
\hline \multicolumn{7}{|l|}{ Wealth Index } \\
\hline Poor & $\begin{array}{l}5670 \\
(24.8)\end{array}$ & $\begin{array}{l}6502 \\
(18.8)\end{array}$ & $\begin{array}{l}32603 \\
(69.4)\end{array}$ & $\begin{array}{l}6395 \\
(26.3)\end{array}$ & $\begin{array}{l}26580 \\
(54.4)\end{array}$ & $4444(62.0)$ \\
\hline Middle & $\begin{array}{l}4323 \\
(18.9)\end{array}$ & $\begin{array}{l}9542 \\
(25.6)\end{array}$ & $\begin{array}{l}7323 \\
(15.6)\end{array}$ & $\begin{array}{l}5636 \\
(23.2)\end{array}$ & $\begin{array}{l}8448 \\
(17.3)\end{array}$ & $1452(20.2)$ \\
\hline Rich & $\begin{array}{l}12863 \\
(56.2)\end{array}$ & $\begin{array}{l}18530 \\
(53.5)\end{array}$ & $\begin{array}{l}7020 \\
(14.9)\end{array}$ & $\begin{array}{l}12209 \\
(50.3)\end{array}$ & $\begin{array}{l}13819 \\
(28.2)\end{array}$ & $1268(17.7)$ \\
\hline \multicolumn{7}{|l|}{ Employment } \\
\hline Did not work & $\begin{array}{l}3413 \\
(86.7)\end{array}$ & $\begin{array}{l}5376 \\
(81.8)\end{array}$ & $\begin{array}{l}6713 \\
(86.5)\end{array}$ & $\begin{array}{l}3801 \\
(78.6)\end{array}$ & $\begin{array}{l}6560 \\
(83.3)\end{array}$ & $1021(86.5)$ \\
\hline Worked & 521 (13.2) & $\begin{array}{l}1192 \\
(18.1)\end{array}$ & $\begin{array}{l}1047 \\
(13.5)\end{array}$ & $\begin{array}{l}1031 \\
(21.3)\end{array}$ & $\begin{array}{l}1313 \\
(16.7)\end{array}$ & $158(134)$ \\
\hline
\end{tabular}


Mother's Education

\begin{tabular}{|c|c|c|c|c|c|c|}
\hline No Education & $\begin{array}{l}6514 \\
(28.5)\end{array}$ & $\begin{array}{l}4237 \\
(12.2)\end{array}$ & $\begin{array}{l}17588 \\
(37.4)\end{array}$ & $\begin{array}{l}3231 \\
(13.3)\end{array}$ & $\begin{array}{l}17985 \\
(36.8)\end{array}$ & $1448(20.2)$ \\
\hline Primary & $\begin{array}{l}3091 \\
(13.5)\end{array}$ & $3042(8.7)$ & $\begin{array}{l}7069 \\
(15.0)\end{array}$ & $\begin{array}{l}2891 \\
(11.9)\end{array}$ & $\begin{array}{l}7520 \\
(15.4)\end{array}$ & $1215(16.9)$ \\
\hline Secondary & $\begin{array}{l}13250 \\
(57.5)\end{array}$ & $\begin{array}{l}27295 \\
(78.9)\end{array}$ & $\begin{array}{l}22289 \\
(47.4)\end{array}$ & $\begin{array}{l}18117 \\
(74.7)\end{array}$ & $\begin{array}{l}23343 \\
(47.8)\end{array}$ & $4502(62.8)$ \\
\hline \multicolumn{7}{|l|}{ Mother's Marital Status } \\
\hline Currently married & $\begin{array}{l}22626 \\
(99.0)\end{array}$ & $\begin{array}{l}34023 \\
(98.5)\end{array}$ & $\begin{array}{l}46362 \\
(98.8)\end{array}$ & $\begin{array}{l}23825 \\
(98.4)\end{array}$ & $\begin{array}{l}48267 \\
(98.8)\end{array}$ & $6995(97.7)$ \\
\hline Formerly married & $212(0.9)$ & $522(1.5)$ & $531(1.1)$ & $373(1.5)$ & $548(1.2)$ & $159(2.2)$ \\
\hline \multicolumn{7}{|l|}{$\begin{array}{l}\text { Combined Birth Rank } \\
\text { and Birth Interval }\end{array}$} \\
\hline 1st child & $\begin{array}{l}7774 \\
(34.0)\end{array}$ & $\begin{array}{l}13147 \\
(38.0)\end{array}$ & $\begin{array}{l}15732 \\
(33.5)\end{array}$ & $\begin{array}{l}8966 \\
(36.9)\end{array}$ & $\begin{array}{l}13545 \\
(27.7)\end{array}$ & $2833(39.5)$ \\
\hline 2nd/3rd >2years & $\begin{array}{l}9604 \\
(42.0)\end{array}$ & $\begin{array}{l}14628 \\
(42.3)\end{array}$ & $\begin{array}{l}19880 \\
(42.3)\end{array}$ & $\begin{array}{l}10561 \\
(43.5)\end{array}$ & $\begin{array}{l}19977 \\
(40.9)\end{array}$ & $3096(43.2)$ \\
\hline $2 \mathrm{nd} / 3 \mathrm{rd}<=2$ years & $\begin{array}{l}3948 \\
(17.2)\end{array}$ & $\begin{array}{l}6404 \\
(18.5)\end{array}$ & $\begin{array}{l}6986 \\
(14.8)\end{array}$ & $\begin{array}{l}3892 \\
(16.0)\end{array}$ & $\begin{array}{l}8924 \\
(18.2)\end{array}$ & $632(8.8)$ \\
\hline 4th birth $>2$ years & $1143(5.0)$ & $263(0.7)$ & $3113(6.6)$ & $633(2.6)$ & $4637(9.4)$ & $472(6.5)$ \\
\hline 4th birth $<=2$ years & $387(1.6)$ & $131(0.3)$ & $1235(2.6)$ & $188(0.7)$ & $1764(3.6)$ & $131(1.8)$ \\
\hline \multicolumn{7}{|l|}{ Health knowledge } \\
\hline \multicolumn{7}{|c|}{ Frequency of reading magazine or newspaper } \\
\hline At least once a week & $\begin{array}{l}2774 \\
(13.7)\end{array}$ & $\begin{array}{l}5442 \\
(19.7)\end{array}$ & $3513(7.8)$ & $\begin{array}{l}3697 \\
(17.4)\end{array}$ & $4045(8.8)$ & $586(8.5)$ \\
\hline Less than once a week & $\begin{array}{l}3593 \\
(17.8)\end{array}$ & $\begin{array}{l}5464 \\
(20.9)\end{array}$ & $\begin{array}{l}5212 \\
(11.6)\end{array}$ & $\begin{array}{l}4213 \\
(19.9)\end{array}$ & $\begin{array}{l}6151 \\
(13.4)\end{array}$ & $972(14.2)$ \\
\hline Never & $\begin{array}{l}13784 \\
(68.4)\end{array}$ & $\begin{array}{l}16379 \\
(59.3)\end{array}$ & $\begin{array}{l}36129 \\
(80.5)\end{array}$ & $\begin{array}{l}13260 \\
(62.6)\end{array}$ & $\begin{array}{l}35420 \\
(77.6)\end{array}$ & $5273(77.1)$ \\
\hline \multicolumn{7}{|l|}{$\begin{array}{l}\text { Frequency of listening } \\
\text { radio }\end{array}$} \\
\hline At least once a week & $1278(5.7)$ & $2039(6.2)$ & $2479(5.4)$ & $1547(6.5)$ & $2540(5.3)$ & $340(4.8)$ \\
\hline Less than once a week & $1175(5.2)$ & $1495(4.6)$ & $2251(4.9)$ & $1044(4.4)$ & $2581(5.4)$ & $442(6.3)$ \\
\hline Never & $\begin{array}{l}19749 \\
(88.9)\end{array}$ & $\begin{array}{l}28887 \\
(89.1)\end{array}$ & $\begin{array}{l}40984 \\
(89.6)\end{array}$ & $\begin{array}{l}20905 \\
(88.9)\end{array}$ & $\begin{array}{l}42410 \\
(89.2)\end{array}$ & 6205 (88.8) \\
\hline \multicolumn{7}{|l|}{$\begin{array}{l}\text { Frequency of watching } \\
\text { Television }\end{array}$} \\
\hline At least once a week & $\begin{array}{l}2268 \\
(28.0)\end{array}$ & $\begin{array}{l}1896 \\
(40.4)\end{array}$ & $\begin{array}{l}4828 \\
(16.3)\end{array}$ & $\begin{array}{l}2634 \\
(33.1)\end{array}$ & $\begin{array}{l}5342 \\
(18.8)\end{array}$ & $914(21.2)$ \\
\hline Less than once a week & $\begin{array}{l}1420 \\
(17.5)\end{array}$ & $698(14.9)$ & $\begin{array}{l}3232 \\
(10.9)\end{array}$ & $\begin{array}{l}1374 \\
(17.3)\end{array}$ & $\begin{array}{l}4541 \\
(16.0)\end{array}$ & $872(20.2)$ \\
\hline
\end{tabular}




\begin{tabular}{|c|c|c|c|c|c|c|}
\hline Never & $\begin{array}{l}4386 \\
(54.3)\end{array}$ & $\begin{array}{l}2093 \\
(44.6)\end{array}$ & $\begin{array}{l}21474 \\
(72.7)\end{array}$ & $\begin{array}{l}3934 \\
(49.5)\end{array}$ & $\begin{array}{l}18442 \\
(65.1)\end{array}$ & $2523(58.5)$ \\
\hline \multicolumn{7}{|l|}{$\begin{array}{l}\text { Told about delivery } \\
\text { complications }\end{array}$} \\
\hline Any complications & $\begin{array}{l}13644 \\
(59.7)\end{array}$ & $\begin{array}{l}23317 \\
(67.4)\end{array}$ & $\begin{array}{l}22009 \\
(46.8)\end{array}$ & $\begin{array}{l}14944 \\
(61.6)\end{array}$ & $\begin{array}{l}20306 \\
(41.5)\end{array}$ & $4366(60.9)$ \\
\hline None & $\begin{array}{l}9212 \\
(40.3)\end{array}$ & $\begin{array}{l}11256 \\
(32.5)\end{array}$ & $\begin{array}{l}24937 \\
(53.1)\end{array}$ & $\begin{array}{l}9296 \\
(38.3)\end{array}$ & $\begin{array}{l}28542 \\
(58.4)\end{array}$ & 2799 (39.0) \\
\hline \multicolumn{7}{|l|}{$\begin{array}{l}\text { Post-delivery } \\
\text { complications } \\
\text { knowledge }\end{array}$} \\
\hline Yes & $\begin{array}{l}16797 \\
(73.4)\end{array}$ & $\begin{array}{l}29118 \\
(84.2)\end{array}$ & $\begin{array}{l}28947 \\
(61.6)\end{array}$ & $\begin{array}{l}19118 \\
(78.8)\end{array}$ & $\begin{array}{l}30692 \\
(62.8)\end{array}$ & $4650(64.9)$ \\
\hline None & $\begin{array}{l}6059 \\
(26.5)\end{array}$ & $\begin{array}{l}5455 \\
(15.7)\end{array}$ & $\begin{array}{l}17999 \\
(38.3)\end{array}$ & $\begin{array}{l}5121 \\
(21.1)\end{array}$ & $\begin{array}{l}18155 \\
(37.1)\end{array}$ & $2514(35.0)$ \\
\hline
\end{tabular}

\section{Enabling factors}

\section{Getting medical help for self: Getting permission to go}

\begin{tabular}{lllllll} 
No problem & $\begin{array}{l}14348 \\
(62.7)\end{array}$ & $\begin{array}{l}19681 \\
(56.9)\end{array}$ & $\begin{array}{l}23986 \\
(51.0)\end{array}$ & $\begin{array}{l}11988 \\
(49.4)\end{array}$ & $\begin{array}{l}30505 \\
(62.4)\end{array}$ & $4281(59.7)$ \\
\hline Big problem & 3287 & 7634 & 11537 & 3850 & 9095 & $1042(14.5)$ \\
& $(14.3)$ & $(22.0)$ & $(24.5)$ & $(15.8)$ & $(18.6)$ & \\
Not a big problem & 5221 & 7259 & $\begin{array}{l}11424 \\
(24.3)\end{array}$ & $\begin{array}{l}8402 \\
(34.6)\end{array}$ & $\begin{array}{l}9248 \\
(18.9)\end{array}$ & $1842(25.7)$ \\
& $(22.8)$ & $(21.0)$ & $(24)$. &
\end{tabular}

\section{Getting medical help for self: Getting money needed for treatment}

\begin{tabular}{lllllll} 
No problem & $\begin{array}{l}12434 \\
(54.4)\end{array}$ & $\begin{array}{l}16972 \\
(49.0)\end{array}$ & $\begin{array}{l}11691 \\
(24.9)\end{array}$ & $\begin{array}{l}11419 \\
(47.1)\end{array}$ & $\begin{array}{l}24090 \\
(49.3)\end{array}$ & $1591(22.2)$ \\
\hline Big problem & 3963 & 7742 & 19753 & 3857 & 11799 & $2894(40.3)$ \\
& $(17.3)$ & $(22.3)$ & $(42.0)$ & $(15.9)$ & $(24.1)$ & \\
\hline Not a big problem & 6459 & 9859 & 15502 & 8964 & 12958 & $2679(37.4)$ \\
& $(28.2)$ & $(28.5)$ & $(33.0)$ & $(36.9)$ & $(26.5)$ &
\end{tabular}

\section{Distance to health}

facilities

$\begin{array}{lllllll}\text { No problem } & 9149 & 15399 & 10694 & 9261 & 15623 & 1798(25.0) \\ & (40.0) & (44.5) & (22.7) & (38.2) & (31.9) & \\ \text { Not a big problem } & 7427 & 10709 & 16952 & 9467 & 15748 & 2963(41.3) \\ & (32.5) & (31.0) & (36.1) & (39.0) & (32.2) & \\ \text { Big problem } & 6280 & 8465 & 19301 & 5512 & 17476 & 2404(33.5) \\ & (27.4) & (24.5) & (41.1) & (22.7) & (35.7) & \end{array}$

Getting medical health for self not wanting to go alone

\begin{tabular}{lllllll} 
No problem & $\begin{array}{l}10341 \\
(45.2)\end{array}$ & $\begin{array}{l}19619 \\
(56.7)\end{array}$ & $\begin{array}{l}17295 \\
(36.8)\end{array}$ & $\begin{array}{l}10748 \\
(44.3)\end{array}$ & $\begin{array}{l}22126 \\
(45.3)\end{array}$ & $3942(41.0)$ \\
\hline Big problem & 4955 & 4865 & 13493 & 4215 & 11466 & $1271(17.7)$ \\
\hline
\end{tabular}




\begin{tabular}{|c|c|c|c|c|c|c|}
\hline & $(21.6)$ & $(14.0)$ & $(28.7)$ & (17.3) & $(23.4)$ & \\
\hline Not a big problem & $\begin{array}{l}7560 \\
(33.0)\end{array}$ & $\begin{array}{l}10089 \\
(29.1)\end{array}$ & $\begin{array}{l}16158 \\
(34.4)\end{array}$ & $\begin{array}{l}9277 \\
(38.2)\end{array}$ & $\begin{array}{l}15256 \\
(31.2)\end{array}$ & $2951(41.1)$ \\
\hline \multicolumn{7}{|l|}{$\begin{array}{l}\text { Timing of postnatal } \\
\text { check-up }\end{array}$} \\
\hline $0-2$ days & $\begin{array}{l}5119 \\
(22.4)\end{array}$ & $\begin{array}{l}8668 \\
(25.0)\end{array}$ & $\begin{array}{l}7936 \\
(16.9)\end{array}$ & $\begin{array}{l}5046 \\
(20.8)\end{array}$ & $\begin{array}{l}10356 \\
(21.2)\end{array}$ & $1271(17.7)$ \\
\hline 3-41 days & $\begin{array}{l}2917 \\
(12.7)\end{array}$ & $\begin{array}{l}6020 \\
(17.4)\end{array}$ & $\begin{array}{l}8868 \\
(18.8)\end{array}$ & $\begin{array}{l}3711 \\
(15.3)\end{array}$ & $\begin{array}{l}6680 \\
(13.6)\end{array}$ & $1060(14.8)$ \\
\hline Don't know & $\begin{array}{l}14820 \\
(64.8)\end{array}$ & $\begin{array}{l}19885 \\
(57.5)\end{array}$ & $\begin{array}{l}30142 \\
(64.2)\end{array}$ & $\begin{array}{l}15483 \\
(63.8)\end{array}$ & $\begin{array}{l}31811 \\
(65.1)\end{array}$ & $4833(67.4)$ \\
\hline \multicolumn{7}{|l|}{ Health Services } \\
\hline \multicolumn{7}{|c|}{$\begin{array}{l}\text { Antenatal care service } \\
\text { attendant }\end{array}$} \\
\hline Health practitioner & $\begin{array}{l}19363 \\
(86.7)\end{array}$ & $\begin{array}{l}31983 \\
(93.6)\end{array}$ & $\begin{array}{l}31758 \\
(71.9)\end{array}$ & $\begin{array}{l}21146 \\
(89.5)\end{array}$ & $\begin{array}{l}35466 \\
(76.0)\end{array}$ & $5880(86.1)$ \\
\hline No one & $\begin{array}{l}2699 \\
(12.1)\end{array}$ & $1935(5.6)$ & $\begin{array}{l}11968 \\
(27.1)\end{array}$ & $2323(9.8)$ & $\begin{array}{l}10521 \\
(22.5)\end{array}$ & $900(13.1)$ \\
\hline Traditional & $252(1.1)$ & $226(0.6)$ & $443(1.0)$ & $139(0.5)$ & $650(1.3)$ & $44(0.6)$ \\
\hline \multicolumn{7}{|c|}{$\begin{array}{l}\text { Place received antenatal } \\
\text { care services }\end{array}$} \\
\hline Government & $\begin{array}{l}7206 \\
(46.7)\end{array}$ & $\begin{array}{l}11619 \\
(39.3)\end{array}$ & $\begin{array}{l}6040 \\
(24.7)\end{array}$ & $\begin{array}{l}5108 \\
(27.3)\end{array}$ & $\begin{array}{l}7020 \\
(28.9)\end{array}$ & $2238(56.4)$ \\
\hline Private & $\begin{array}{l}5888 \\
(38.2)\end{array}$ & $\begin{array}{l}14088 \\
(47.7)\end{array}$ & $\begin{array}{l}9268 \\
(37.9)\end{array}$ & $\begin{array}{l}7978 \\
(42.6)\end{array}$ & $\begin{array}{l}11757 \\
(48.4)\end{array}$ & $883(22.2)$ \\
\hline Home & $\begin{array}{l}2313 \\
(15.0)\end{array}$ & $\begin{array}{l}3811 \\
(12.9)\end{array}$ & $\begin{array}{l}9130 \\
(37.3)\end{array}$ & $\begin{array}{l}5605 \\
(29.9)\end{array}$ & $\begin{array}{l}5506 \\
(22.6)\end{array}$ & $841(21.2)$ \\
\hline \multicolumn{7}{|l|}{ Need factors } \\
\hline \multicolumn{7}{|l|}{ Contraceptive use } \\
\hline Yes & $\begin{array}{l}11989 \\
(52.4)\end{array}$ & $\begin{array}{l}14663 \\
(42.4)\end{array}$ & $\begin{array}{l}18429 \\
(39.2)\end{array}$ & $\begin{array}{l}10838 \\
(44.7)\end{array}$ & $\begin{array}{l}19035 \\
(38.9)\end{array}$ & $3634(50.7)$ \\
\hline No & $\begin{array}{l}10867 \\
(47.5)\end{array}$ & $\begin{array}{l}19910 \\
(57.6)\end{array}$ & $\begin{array}{l}28517 \\
(60.7)\end{array}$ & $\begin{array}{l}13401 \\
(55.2)\end{array}$ & $\begin{array}{l}29813 \\
(61.1)\end{array}$ & $3531(49.2)$ \\
\hline \multicolumn{7}{|l|}{$\begin{array}{l}\text { Intention to become } \\
\text { pregnant }\end{array}$} \\
\hline Then & $\begin{array}{l}21003 \\
(91.9)\end{array}$ & $\begin{array}{l}32833 \\
(95.0)\end{array}$ & $\begin{array}{l}41824 \\
(89.1)\end{array}$ & $\begin{array}{l}22594 \\
(93.2)\end{array}$ & $\begin{array}{l}42742 \\
(87.5)\end{array}$ & $6574(91.8)$ \\
\hline Later & $923(4.0)$ & 788 (2.2) & $2353(5.0)$ & $575(2.3)$ & $2669(5.4)$ & $246(3.4)$ \\
\hline No more & $924(4.0)$ & $910(2.6)$ & $2743(5.8)$ & $1057(4.3)$ & $3425(7.0)$ & $341(4.7)$ \\
\hline \multicolumn{7}{|l|}{ Autonomy variables } \\
\hline Power over earnings & & & & & & \\
\hline
\end{tabular}




\begin{tabular}{|c|c|c|c|c|c|c|}
\hline By husband & $\begin{array}{l}20289 \\
(88.7)\end{array}$ & $\begin{array}{l}30405 \\
(87.9)\end{array}$ & $\begin{array}{l}41931 \\
(89.3)\end{array}$ & $\begin{array}{l}21341 \\
(88.0)\end{array}$ & $\begin{array}{l}43590 \\
(89.2)\end{array}$ & $6334(88.4)$ \\
\hline Woman alone & $\begin{array}{l}2567 \\
(11.2)\end{array}$ & $\begin{array}{l}4168 \\
(12.0)\end{array}$ & $\begin{array}{l}5016 \\
(10.6)\end{array}$ & $\begin{array}{l}2899 \\
(12.0)\end{array}$ & $\begin{array}{l}5258 \\
(10.7)\end{array}$ & $830(11.5)$ \\
\hline \multicolumn{7}{|c|}{ Power over household decision making } \\
\hline By husband & $\begin{array}{l}19765 \\
(86.4)\end{array}$ & $\begin{array}{l}29379 \\
(85)\end{array}$ & $\begin{array}{l}40807 \\
(86.9)\end{array}$ & $\begin{array}{l}20248 \\
(83.5)\end{array}$ & $\begin{array}{l}42630 \\
(87.2)\end{array}$ & $6164(86.0)$ \\
\hline Woman alone & $\begin{array}{l}3090 \\
(13.5)\end{array}$ & $5194(15)$ & $\begin{array}{l}6139 \\
(13.1)\end{array}$ & $\begin{array}{l}3991 \\
(16.5)\end{array}$ & $\begin{array}{l}6217 \\
(12.7)\end{array}$ & 1001 (13.9) \\
\hline \multicolumn{7}{|c|}{$\begin{array}{l}\text { Wife beaten for refusing } \\
\text { sex }\end{array}$} \\
\hline Yes & $445(11.3)$ & $\begin{array}{l}1298 \\
(19.7)\end{array}$ & $\begin{array}{l}1227 \\
(15.8)\end{array}$ & $551(11.4)$ & $\begin{array}{l}1074 \\
(13.6)\end{array}$ & $156(13.2)$ \\
\hline No & $\begin{array}{l}3489 \\
(88.6)\end{array}$ & $\begin{array}{l}5270 \\
(80.2)\end{array}$ & $\begin{array}{l}6533 \\
(84.1)\end{array}$ & $\begin{array}{l}4281 \\
(88.6)\end{array}$ & $\begin{array}{l}6799 \\
(86.3)\end{array}$ & $1023(86.7)$ \\
\hline \multicolumn{7}{|c|}{$\begin{array}{l}\text { Attitudes to domestic } \\
\text { violence }\end{array}$} \\
\hline Yes & $1124(4.9)$ & $\begin{array}{l}4578 \\
(13.2)\end{array}$ & $3443(7.3)$ & $1665(6.8)$ & $3297(6.7)$ & $445(6.2)$ \\
\hline No & $\begin{array}{l}21732 \\
(95.0)\end{array}$ & $\begin{array}{l}29995 \\
(86.7)\end{array}$ & $\begin{array}{l}43503 \\
(92.6)\end{array}$ & $\begin{array}{l}22574 \\
(93.2)\end{array}$ & $\begin{array}{l}45551 \\
(93.2)\end{array}$ & $6720(93.7)$ \\
\hline
\end{tabular}

Table 2: Regional prevalence and 95\% confidence intervals (Cls) of components of antenatal care received by Indian women during last pregnancy, NFSH-4. 


\begin{tabular}{|c|c|c|c|c|c|c|c|}
\hline \multirow[t]{2}{*}{ Component } & North & South & East & West & Central & $\begin{array}{l}\text { North } \\
\text { Eastern }\end{array}$ & National \\
\hline & $\%(95 \% \mathrm{Cl})$ & $\begin{array}{l}\% \\
(95 \% \mathrm{Cl})\end{array}$ & $\begin{array}{l}\% \\
(95 \% \mathrm{Cl})\end{array}$ & $\begin{array}{l}\% \\
(95 \% \mathrm{Cl})\end{array}$ & $\begin{array}{l}\% \\
(95 \% \mathrm{Cl})\end{array}$ & $\begin{array}{l}\% \\
(95 \% \mathrm{Cl})\end{array}$ & $\begin{array}{l}\% \\
(95 \% \mathrm{Cl})\end{array}$ \\
\hline $\begin{array}{l}\text { Told about pregnancy } \\
\text { complications }\end{array}$ & $\begin{array}{l}59.7(58.5 \\
60.9)\end{array}$ & $\begin{array}{l}67.4 \\
(66.2 \\
68.6)\end{array}$ & $\begin{array}{l}46.9 \\
(45.8 \\
47.9)\end{array}$ & $\begin{array}{l}61.5 \\
(59.7 \\
63.5)\end{array}$ & $\begin{array}{l}41.5 \\
(40.8 \\
42.3)\end{array}$ & $\begin{array}{l}60.9 \\
(59.4 \\
62.3)\end{array}$ & $\begin{array}{l}53.4 \\
(52.8 \\
53.9)\end{array}$ \\
\hline $\begin{array}{l}\text { During pregnancy given iron } \\
\text { tablets }\end{array}$ & $\begin{array}{l}76.1 \\
(75.2,77.1)\end{array}$ & $\begin{array}{l}91.4 \\
(90.7 \\
92.1)\end{array}$ & $\begin{array}{l}73(72.2 \\
73.9)\end{array}$ & $\begin{array}{l}82.4 \\
(81.1 \\
83.5)\end{array}$ & $\begin{array}{l}71(70.3 \\
71.6)\end{array}$ & $\begin{array}{l}83.4 \\
(82.3 \\
84.4)\end{array}$ & $\begin{array}{l}77.9 \\
(77.6 \\
78.3)\end{array}$ \\
\hline $\begin{array}{l}\text { Drugs for intestinal } \\
\text { parasites during pregnancy }\end{array}$ & $\begin{array}{l}12.0(11.3 \\
12.6)\end{array}$ & $\begin{array}{l}32.1(30, \\
33.3)\end{array}$ & $\begin{array}{l}15.6 \\
(14.9 \\
16.3)\end{array}$ & $\begin{array}{l}24.7 \\
(23.3 \\
26.1)\end{array}$ & $\begin{array}{l}11.9 \\
(11.5 \\
12.4)\end{array}$ & $\begin{array}{l}8.4(7.6 \\
9.3)\end{array}$ & $\begin{array}{l}18.1 \\
(17.8 \\
18.5)\end{array}$ \\
\hline $\begin{array}{l}\text { Number of tetanus injection } \\
\text { before birth }\end{array}$ & $\begin{array}{l}83.9(83.1 \\
84.5)\end{array}$ & $\begin{array}{l}81.0 \\
(80.0 \\
82.0)\end{array}$ & $\begin{array}{l}86.4 \\
(85.8 \\
87.0)\end{array}$ & $\begin{array}{l}82.2 \\
(81.0 \\
83.4)\end{array}$ & $\begin{array}{l}83.1 \\
(82.5 \\
83.6)\end{array}$ & $\begin{array}{l}82.3 \\
(81.2 \\
83.3)\end{array}$ & $\begin{array}{l}83.5 \\
(83.1 \\
83.8)\end{array}$ \\
\hline $\begin{array}{l}\text { During pregnancy: blood } \\
\text { pressure taken }\end{array}$ & $\begin{array}{l}93.8(93.2, \\
94.2)\end{array}$ & $\begin{array}{l}99.2 \\
(99.1 \\
99.4)\end{array}$ & $\begin{array}{l}87.7 \\
(87.0 \\
88.3)\end{array}$ & $\begin{array}{l}97.3 \\
(97.0 \\
97.7)\end{array}$ & $\begin{array}{l}74.5 \\
(73.8 \\
75.2)\end{array}$ & $\begin{array}{l}96.8 \\
(96.4 \\
97.1)\end{array}$ & $\begin{array}{l}89.4 \\
(89.1 \\
89.6)\end{array}$ \\
\hline $\begin{array}{l}\text { During pregnancy: blood } \\
\text { sample taken }\end{array}$ & $\begin{array}{l}93.4(93 \\
94)\end{array}$ & $\begin{array}{l}99.1 \\
(98.9 \\
99.2)\end{array}$ & $\begin{array}{l}81.7 \\
(80.9 \\
82.4)\end{array}$ & $\begin{array}{l}96.5 \\
(96.0 \\
97.0)\end{array}$ & $\begin{array}{l}73.6 \\
(72.9 \\
74.3)\end{array}$ & $\begin{array}{l}89.3 \\
(88.3 \\
90.2)\end{array}$ & $\begin{array}{l}87.3 \\
(87.0 \\
87.6)\end{array}$ \\
\hline $\begin{array}{l}\text { During pregnancy: urine } \\
\text { sample taken }\end{array}$ & $\begin{array}{l}92.4(91.8, \\
93)\end{array}$ & $\begin{array}{l}99.2(99, \\
99.3)\end{array}$ & $\begin{array}{l}85.1 \\
(84.3 \\
85.8)\end{array}$ & $\begin{array}{l}96.1 \\
(95.6 \\
96.6)\end{array}$ & $\begin{array}{l}73.8 \\
(73.1 \\
74.4)\end{array}$ & $\begin{array}{l}88.2 \\
(87.3 \\
89.1)\end{array}$ & $\begin{array}{l}87.9 \\
(87.6 \\
88.2)\end{array}$ \\
\hline During pregnancy weighed & $\begin{array}{l}93.8(93.3 \\
94.2)\end{array}$ & $\begin{array}{l}99.3 \\
(99.2 \\
99.5)\end{array}$ & $\begin{array}{l}90.7 \\
(90.1 \\
91.2)\end{array}$ & $\begin{array}{l}98.0 \\
(97.6 \\
98.3)\end{array}$ & $\begin{array}{l}75.5 \\
(74.7 \\
76.1)\end{array}$ & $\begin{array}{l}97.3 \\
(97.0 \\
97.6)\end{array}$ & $\begin{array}{l}90.4 \\
(90.2 \\
90.7\end{array}$ \\
\hline Abdomen examined & $\begin{array}{l}90.6(90 \\
91.1)\end{array}$ & $\begin{array}{l}98.0 \\
(97.7 \\
98.3)\end{array}$ & $\begin{array}{l}80.9 \\
(80.0 \\
81.8)\end{array}$ & $\begin{array}{l}94.9 \\
(94.2 \\
95.4)\end{array}$ & $\begin{array}{l}82.7 \\
(82.1, \\
83.2)\end{array}$ & $\begin{array}{l}89.6 \\
(88.5 \\
90.6)\end{array}$ & $\begin{array}{l}88.6 \\
(88.3 \\
88.8)\end{array}$ \\
\hline
\end{tabular}


Table 3. Factor associated with inadequate receipt of ANC. Using adequate receipt of the components of ANC as the Standard of Comparison

Variable

$\begin{array}{llllll}\text { North } & \text { South } & \text { East } & \text { West } & \text { Central } & \text { North East } \\ \text { AOR }(95 \% & \text { AOR }(95 \% & \text { AOR }(95 \% & \text { AOR }(95 \% & \text { AOR }(95 \% & \text { AOR }(95 \% \\ \text { Cl) } & \text { Cl) } & \text { Cl) } & \text { Cl) } & \text { Cl) } & \text { Cl) }\end{array}$

Type of residence

Urban

1.00

Rural

Mother's age at birth

$<20$ years

1.00

1.00

1.00

20-29 years

$0.69(0.58, \quad 0.89(0.73$,

$0.81)$

1.08)

$0.85(0.71$

1.01)

30-39 years

0.49 (0.39, $\quad 0.68(0.51$,

0.60) 0.90)

$0.74(0.59$

0.93)

$40+$ years

$\begin{array}{ll}0.58(0.34, & 0.28(0.86 \\ 0.99) & 0.95)\end{array}$

$0.53(0.31$ $0.87)$

\section{Place of birth}

Home

1.00

1.00

1.00

1.00

1.00

Health facility

$\begin{array}{ll}0.70(0.60, & 0.63(0.47 \\ 0.82) & 0.85)\end{array}$

0.72

$(0.58,0.90)$

$0.59(0.52$

$0.54(0.45$

$0.82) \quad 0.85)$

$0.67)$

$0.65)$

Household wealth index

Poor

1.00

1.00

1.00

1.00

1.00

1.00

Middle

$0.89(0.77$

$0.89(0.76$

$0.84(0.69$,

1.03)

1.05)

1.03)

$0.71(0.59$,

$0.86)$

$0.83(0.73$,

0.94)

$0.71(0.61$,

$0.64(0.56$

0.73 (0.61,

$0.56(0.41$,

$0.73)$

$0.89)$

$0.77)$

$0.51(0.41$

$0.63)$

$0.71(0.61$,

$0.83)$

$0.83)$

Mother's education

No education

1.00

1.00

1.00

1.00

1.00

Primary Education

$0.94(0.79$,

1.12)

$0.82(0.64$

1.05)

$0.63(0.52$

$0.75)$

$0.90(0.79, \quad 0.94(0.78$,

$0.70(0.62, \quad 0.68(0.56, \quad 0.53(0.45$,

Secondary Education or

more

0.79)

$0.82)$

$0.62)$

1.02)

1.14)

Combined Birth rank and

Birth Interval

2nd or 3rd rank $>2 y$ interval 1.00

1.00

1.00

1.00

1.00

1st birth rank

$0.80(0.72$,

$0.90)$

$0.73(0.64$

$0.83)$

$0.87(0.74$

1.03)

$0.81(0.73$

$0.91)$

$0.74(0.63$

$0.88)$

$0.56(0.46$

2nd/3rd birth rank $<=2 \mathrm{y}$

interval

$1.26(1.13$,

$1.25(1.05, \quad 1.57(1.24$,

1.48)

1.99)

$0.79(0.70$

$0.88)$

$0.83(0.72$,

$0.96)$

1.41)

$\begin{array}{ll}1.01(0.89, & 1.19(0.98, \\ 1.14) & 1.46)\end{array}$ 
4th birth rank $>2 y$ interval

$1.47(1.17$

1.83)

1.67 (1.28,

2.18)

$1.38(0.97$

$1.32(1.10$

1.58)

1.32 (1.01,

$2.07(1.25$

$3.44)$

1.96)

1.73)

4th birth rank $<=2 \mathrm{y}$ interval 1.60 (1.11,

2.29)

(4)

$1.80(1.01$,

3.20)

$1.22(0.95$,

1.57)

1.42 (0.93,

2.17)

\section{Listening radio}

\begin{tabular}{llll} 
At least once a week & 1.00 & 1.00 & 1.00 \\
\hline Less than once a week & $1.02(0.76$, & $1.51(1.02$, & $1.41(0.84$, \\
& $1.37)$ & $2.25)$ & $2.37)$ \\
\hline Never & $1.80(1.45$, & $0.88(0.64$, & $0.60(0.44$, \\
& $2.23)$ & $1.22)$ & $0.80)$
\end{tabular}

\section{Reading magazines}

At least once a week

1.00

Less than once a week

$0.93(0.68$

1.26)

Never

$0.77(0.58$

1.01)

\section{Watching TV}

At least once a week

1.00

1.00

Less than once a week

1.20 (0.96,

1.50)

$1.29(1.12$

1.49)

Never

$1.65(1.39$,

1.96)

1.41 (1.25,

1.58)

Told about Delivery

complications

$\begin{array}{lllllll}\text { Yes } & 1.00 & 1.00 & 1.00 & 1.00 & 1.00 & 1.00 \\ \text { No } & 1.36(1.21, & 1.56(1.31, & 2.16(1.90, & 2.13(1.77, & 1.61(1.46, & 1.65(1.44, \\ & 1.54) & 1.86) & 2.47) & 2.56) & 1.77) & 1.90)\end{array}$

Post-delivery complications

knowledge

$\begin{array}{lllllll}\text { Yes } & 1.00 & 1.00 & 1.00 & 1.00 & 1.00 & 1.00 \\ \text { No } & 1.23(1.05, & 1.22(1.00, & 1.51(1.30, & 1.40(1.14, & 1.37(1.21, & 1.60(1.35, \\ & 1.43) & 1.48) & 1.76) & 1.71) & 1.56) & 1.90)\end{array}$

Money to pay for health

services

No problem

$\begin{array}{lll}1.00 & 1.00 & 1.00\end{array}$

Not a big problem

$\left.\begin{array}{lll}1.06(0.92, & 1.42\left(\begin{array}{ll}1.12, & 0.40 \\ 1.23) & 1.80\end{array}\right) & 0.49\end{array}\right)$

1.80)

$0.49)$

1.20 (1.07, $\quad 1.24(1.01, \quad 0.62$ (0.51,

$\begin{array}{lll}1.35) & 1.52) & 0.75)\end{array}$

$1.00 \quad 1.00$

Big problem

$1.28(1.13,1.07(0.87$,

1.45) 1.31)

$1.26(1.12, \quad 1.23(1.03$,

1.41) 1.46)

Not wanting to go alone to health care 


\begin{tabular}{lllll} 
No problem & 1.00 & 1.00 & 1.00 & 1.00 \\
Not a big problem & $1.19(1.04$, & $0.72(0.56$, & $1.24(1.03$, & $1.14(0.92$, \\
& $1.36)$ & $0.93)$ & $1.49)$ & $1.42)$ \\
\hline Big problem & $1.11(0.99$, & $1.11(0.92$, & $1.37(1.17$, & $1.11(0.96$, \\
& $1.24)$ & $1.34)$ & $1.60)$ & $1.28)$
\end{tabular}

\section{Permission to visit health services}

\begin{tabular}{lllll} 
No problem & 1.00 & 1.00 & 1.00 & 1.00 \\
\hline Not a big problem & $1.52(1.20$, & $2.07(1.72$, & $1.56(1.21$, & $1.29(1.01$, \\
& $1.93)$ & $2.50)$ & $2.02)$ & $1.65)$ \\
\hline Big problem & $1.68(1.35$, & $1.35(1.14$, & $1.15(0.93$, & $1.28(1.07$, \\
& $2.09)$ & $1.60)$ & $1.41)$ & $1.52)$
\end{tabular}

\section{Distance to a health facility}

\begin{tabular}{lll} 
No problem & 1.00 & 1.00 \\
\hline Not a big problem & $1.19(0.97$, & $1.27(1.05$, \\
& $1.45)$ & $1.54)$ \\
\hline Big problem & $1.53(1.22$, & $1.12(0.91$, \\
& $1.93)$ & $1.37)$
\end{tabular}

Antenatal care receives at:

\begin{tabular}{|c|c|c|c|c|c|}
\hline Government hospital & 1.00 & 1.00 & 1.00 & 1.00 & 1.00 \\
\hline Private centre & $\begin{array}{l}1.16(1.05, \\
1.28)\end{array}$ & $\begin{array}{l}0.99(0.84, \\
1.17)\end{array}$ & $\begin{array}{l}1.06(0.90, \\
1.25)\end{array}$ & $\begin{array}{l}0.70(0.62, \\
0.78)\end{array}$ & $\begin{array}{l}0.62(0.53, \\
0.73)\end{array}$ \\
\hline Home & $\begin{array}{l}1.20(1.04, \\
1.39)\end{array}$ & $\begin{array}{l}0.42(0.31 \\
0.56)\end{array}$ & $\begin{array}{l}0.79(0.67, \\
0.94)\end{array}$ & $\begin{array}{l}0.58(0.51 \\
0.67)\end{array}$ & $\begin{array}{l}1.10(0.92, \\
1.33)\end{array}$ \\
\hline
\end{tabular}

Timing of Post-natal check-

up

\begin{tabular}{|c|c|c|c|c|c|}
\hline $0-2$ days & 1.00 & 1.00 & 1.00 & 1.00 & 1.00 \\
\hline 3-41days & $\begin{array}{l}1.22(1.04, \\
1.43)\end{array}$ & $\begin{array}{l}1.12(0.89, \\
1.41)\end{array}$ & $\begin{array}{l}0.93(0.76, \\
1.14)\end{array}$ & $\begin{array}{l}0.97(0.83, \\
1.12)\end{array}$ & $\begin{array}{l}0.93(0.74, \\
1.16)\end{array}$ \\
\hline No post-natal check & $\begin{array}{l}1.65(1.44, \\
1.88)\end{array}$ & $\begin{array}{l}1.59(1.30, \\
1.95)\end{array}$ & $\begin{array}{l}1.59(1.34, \\
1.88)\end{array}$ & $\begin{array}{l}1.36(1.20, \\
1.55)\end{array}$ & $\begin{array}{l}0.85(0.71, \\
1.02)\end{array}$ \\
\hline
\end{tabular}

\section{Contraceptive use}

$\begin{array}{llllll}\text { Yes } & 1.00 & 1.00 & 1.00 & 1.00 & 1.00 \\ \text { No } & 1.29(1.16, & 2.01(1.72, & 1.18(1.02, & 1.17(1.06, & 1.13(1.00 \\ & 1.42) & 2.34) & 1.37) & 1.29) & 1.28)\end{array}$

\section{Wanted pregnancy}

$\begin{array}{llll}\text { Now } & 1.00 & 1.00 & 1.00 \\ \text { Later } & 0.82(0.66, & 1.16(0.96, & 1.12(0.82, \\ & 1.02) & 1.41) & 1.51) \\ \text { No more } & 1.35(1.06, & 1.39(1.15, & 1.70(1.24, \\ & 1.71) & 1.68) & 2.32)\end{array}$




\section{Power over earnings}

By Husband alone

1.00

Alone/joint decision

$0.74(0.65$

$0.82)$

\section{Domestic Violence}

$\begin{array}{ll}\text { Yes } & 1.00 \\ \text { No } & 0.74(0.59, \\ & 0.93)\end{array}$

If $95 \%$ confidence intervals $(\mathrm{Cl})$ around ORs that lies between 1.00 indicate not statistically significant. All comparisons were made against adequate receipt of the components of ANC (OR=1.0). 
Table 4. Factor associated with No ANC. Using adequate receipt of the components of ANC as the Standard of Comparison

Variable

\begin{tabular}{|c|c|c|c|c|c|}
\hline North & South & East & West & Central & North East \\
\hline $\begin{array}{l}\text { AOR (95\% } \\
\mathrm{Cl})\end{array}$ & $\begin{array}{l}\mathrm{AOR}(95 \% \\
\mathrm{Cl})\end{array}$ & $\begin{array}{l}\text { AOR (95\% } \\
\mathrm{Cl})\end{array}$ & $\begin{array}{l}\text { AOR (95\% } \\
\mathrm{Cl})\end{array}$ & $\begin{array}{l}\text { AOR }(95 \% \\
\mathrm{Cl})\end{array}$ & $\begin{array}{l}\text { AOR }(95 \% \\
\mathrm{Cl})\end{array}$ \\
\hline
\end{tabular}

Type of residence

Urban

1.00

Rural

$1.11(0.76$

1.62)

Mother's age at Birth

$<20$ years

1.00

1.00

1.00

1.00

1.00

20-29 years

$0.84(0.60, \quad 1.10(0.79$,

1.17)

1.54)

1.29 (0.86,

1.94)

30-39 years

$0.93(0.60, \quad 1.44(0.93$,

$1.58(0.98$

1.46) 2.22)

2.56)

$40+$ years

$0.28(0.64, \quad 1.91(0.40$,

$2.25(0.83$

1.20) 8.99)

6.06)

\section{Place of birth}

Home

1.00

1.00

1.00

1.00

1.00

Health facility

$0.68(0.47, \quad 0.93(0.42$,

$0.98)$

2.05)

$0.70(0.45$,

1.10)

$0.72(0.54$,

$0.95)$

$0.67(0.47$ $0.96)$

Household wealth index

Poor

1.00

1.00

1.00

1.00

1.00

1.00

Middle

0.87 (0.59,

$0.90(0.67$,

$1.26(0.78$

$0.85(0.59$

1.28)

1.22)

2.02)

1.22)

$0.63(0.46$,

$0.87)$

$1.18(0.83$,

0.94 (0.66,

$1.12(0.80$

0.89 (0.47,

0.71 (0.51,

$0.62(0.42$,

0.99)

$0.93)$

1.68)

1.35)

1.57)

1.66)

$0.87(0.56$,

Mother's education

No education

1.00

1.00

1.00

1.00

1.00

Primary Education

$0.78(0.55$,

1.12)

$1.31(0.75$

2.28)

$0.51(0.32$,

$0.80)$

$0.91(0.67$,

1.23)

0.91 (0.58,

$0.77(0.58, \quad 1.37(0.95, \quad 0.43(0.29$,

1.03)

1.99)

$0.63)$

0.85 (0.64,

1.12)

1.42)

Secondary Education or

more

Combined Birth rank and

Birth Interval

\begin{tabular}{llllll} 
2nd or 3rd rank>2y interval & 1.00 & 1.00 & 1.00 & 1.00 & 1.00 \\
\hline 1st birth rank & $0.89(0.71$, & $0.90(0.65$, & $0.84(0.61$, & $0.92(0.68$, & $1.35(0.99$, \\
& $1.13)$ & $1.26)$ & $1.15)$ & $1.24)$ & $1.83)$ \\
& $1.06(0.78$, & $1.30(0.84$, & $0.97(0.67$, & $1.47(1.09$, & $0.63(0.37$, \\
2nd/3rd birth rank <= 2y & $1.45)$ & $2.00)$ & $1.40)$ & $1.98)$ & $1.10)$
\end{tabular}


4th birth rank $>2 y$ interval $0.93(0.50$, 1.76)

4th birth rank $<=2 y$ interval $1.39(0.60$, 3.24)
1.20 (0.69, 0.89 (0.46,

2.06)

$1.27(0.48$

3.33)
1.71)

$3.47(0.95$, 12.66)
1.91 (1.29,

2.84)

$1.07(0.60$ 1.90)

$1.35(0.78, \quad 1.02(0.40$, 2.33)

\section{Listening radio}

At least once a week

1.00

1.00

1.00

Less than once a week

$2.95(1.62$

5.38)

$1.15(0.51$,

$1.38(0.61$,

2.59)

3.11)

Never

$3.07(1.95$,
$4.85)$

$0.70(0.34$,

1.47)

0.77 (0.47,

1.26)

\section{Reading magazines}

At least once a week

1.00

Less than once a week

$0.92(0.48$,

1.74)

Never

$0.53(0.28$,

$0.99)$

\section{Watching TV}

At least once a week

Less than once a week

1.00

$1.06(0.67$,

1.69)

1.49 (1.01,

2.22)
1.00

$0.76(0.54$ 1.06)

$0.88(0.67$

1.16)

\section{Told about Delivery}

complications

\begin{tabular}{|c|c|c|c|c|c|c|}
\hline Yes & 1.00 & 1.00 & 1.00 & 1.00 & 1.00 & 1.00 \\
\hline No & $\begin{array}{l}0.42(0.30 \\
0.58)\end{array}$ & $\begin{array}{l}0.46(0.35, \\
0.61)\end{array}$ & $\begin{array}{l}0.70(0.48, \\
1.00)\end{array}$ & $\begin{array}{l}0.32(0.21, \\
0.49)\end{array}$ & $\begin{array}{l}0.49(0.38, \\
0.62)\end{array}$ & $\begin{array}{l}0.69 \text { (0.49, } \\
0.97)\end{array}$ \\
\hline
\end{tabular}

\section{Post-delivery}

complications knowledge

$\begin{array}{lllllll}\text { Yes } & 1.00 & 1.00 & 1.00 & 1.00 & 1.00 & 1.00 \\ \text { No } & 0.85(0.59, & 0.95(0.66, & 0.96(0.68, & 0.97(0.66, & 1.34(1.01, & 2.28(1.62, \\ & 1.20) & 1.36) & 1.35) & 1.42) & 1.79) & 3.22)\end{array}$

\section{Money to pay for health}

services

No problem

1.00

1.00

1.00

1.00

1.00

Not a big problem

$1.75(1.22$

$0.84(0.54$

1.30)

$0.66(0.40$,

1.08)

$1.10(0.82, \quad 1.09(0.69$,

Big problem

\begin{tabular}{|c|c|}
\hline $\begin{array}{l}.51(1.16, \\
97)\end{array}$ & $\begin{array}{l}1.29(0.87, \\
1.89)\end{array}$ \\
\hline
\end{tabular}

1.47)

1.72)

1.19 (0.90, 0.89 (0.61,

1.57)

1.31)

Not wanting to go alone to

health care 


\begin{tabular}{lllll} 
No problem & 1.00 & 1.00 & 1.00 & 1.00 \\
\hline Not a big problem & $0.84(0.61$, & $1.32(0.87$, & $1.56(1.07$, & $0.47(0.29$, \\
& $1.16)$ & $2.01)$ & $2.28)$ & $0.75)$ \\
\hline Big problem & $0.95(0.71$, & $1.16(0.82$, & $1.13(0.78$, & $0.69(0.51$, \\
& $1.26)$ & $1.65)$ & $1.63)$ & $0.93)$
\end{tabular}

\section{Permission to visit health services}

\begin{tabular}{lllll} 
No problem & 1.00 & 1.00 & 1.00 & 1.00 \\
Not a big problem & $1.03(0.65$, & $2.59(1.59$, & $1.94(1.26$, & $3.04(2.02$, \\
& $1.63)$ & $4.20)$ & $2.98)$ & $4.55)$ \\
\hline Big problem & $0.79(0.50$, & $1.67(1.15$, & $1.14(0.77$, & $1.40(0.99$, \\
& $1.24)$ & $2.41)$ & $1.69)$ & $1.99)$
\end{tabular}

\section{Distance to health facility}

\begin{tabular}{lll} 
No problem & 1.00 & 1.00 \\
\hline Not a big problem & $0.99(0.74$, & $0.88(0.54$, \\
& $1.34)$ & $1.43)$ \\
\hline Big problem & $1.19(0.80$, & $0.71(0.44$, \\
$1.78)$ & $1.15)$
\end{tabular}

Antenatal care receives at:

\begin{tabular}{|c|c|c|c|c|c|}
\hline Government & 1.00 & 1.00 & 1.00 & 1.00 & 1.00 \\
\hline Private centre & $\begin{array}{l}0.60(0.46, \\
0.79)\end{array}$ & $\begin{array}{l}0.65(0.48, \\
0.89)\end{array}$ & $\begin{array}{l}0.59(0.42, \\
0.84)\end{array}$ & $\begin{array}{l}0.53(0.38, \\
0.74)\end{array}$ & $\begin{array}{l}0.53(0.31, \\
0.90)\end{array}$ \\
\hline Home & $\begin{array}{l}1.00(0.75, \\
1.34)\end{array}$ & $\begin{array}{l}1.39(0.99, \\
1.97)\end{array}$ & $\begin{array}{l}0.88(0.63, \\
1.24)\end{array}$ & $\begin{array}{l}1.03(0.77 \\
1.36)\end{array}$ & $\begin{array}{l}3.98(2.91, \\
5.45)\end{array}$ \\
\hline
\end{tabular}

Timing of Post-natal check-up

\begin{tabular}{|c|c|c|c|c|c|}
\hline $0-2$ days & 1.00 & 1.00 & 1.00 & 1.00 & 1.00 \\
\hline 3-41 days & $\begin{array}{l}1.69 \\
2.35)\end{array}$ & $\begin{array}{l}1.01(0.75 \\
1.36)\end{array}$ & $\begin{array}{l}0.89(0.55 \\
(1.44)\end{array}$ & $\begin{array}{l}1.10(0.76, \\
1.61)\end{array}$ & $\begin{array}{l}2.00(1.24, \\
3.22)\end{array}$ \\
\hline No post-natal check & $\begin{array}{l}1.09(0.82, \\
1.44)\end{array}$ & $\begin{array}{l}0.83(0.62, \\
1.12)\end{array}$ & $\begin{array}{l}1.54(1.04, \\
2.28)\end{array}$ & $\begin{array}{l}1.81(1.29, \\
2.53)\end{array}$ & $\begin{array}{l}1.23(0.82, \\
1.84)\end{array}$ \\
\hline
\end{tabular}

\section{Contraceptive use}

$\begin{array}{llllll}\text { Yes } & 1.00 & 1.00 & 1.00 & 1.00 & 1.00 \\ \text { No } & 0.89(0.71, & 1.39(0.98, & 1.71(1.16, & 1.16(0.91, & 0.71(0.55, \\ & 1.12) & 1.99) & 2.54) & 1.49) & 0.92)\end{array}$

Wanted pregnancy

$\begin{array}{llll}\text { Now } & 1.00 & 1.00 & 1.00 \\ \text { Later } & 0.40(0.23, & 1.24(0.79, & 0.86(0.38, \\ & 0.67) & 1.96) & 1.92) \\ \text { No more } & 1.23(0.74, & 0.98(0.58, & 0.92(0.42, \\ & 2.05) & 1.64) & 2.02)\end{array}$




\section{Power over earnings}

$\begin{array}{ll}\text { By Husband alone } & 1.00 \\ \text { Alone/joint decision } & 0.56(0.39, \\ & 0.80)\end{array}$

\section{Domestic Violence}

$\begin{array}{ll}\text { Yes } & 1.00 \\ \text { No } & 0.82(0.51, \\ & 1.33)\end{array}$

If $95 \%$ confidence intervals $(\mathrm{Cl})$ around ORs that lies between 1.00 indicate not statistically significant. All comparisons were made against adequate receipt of the components of ANC $(\mathrm{OR}=1.0)$

\section{Figures}




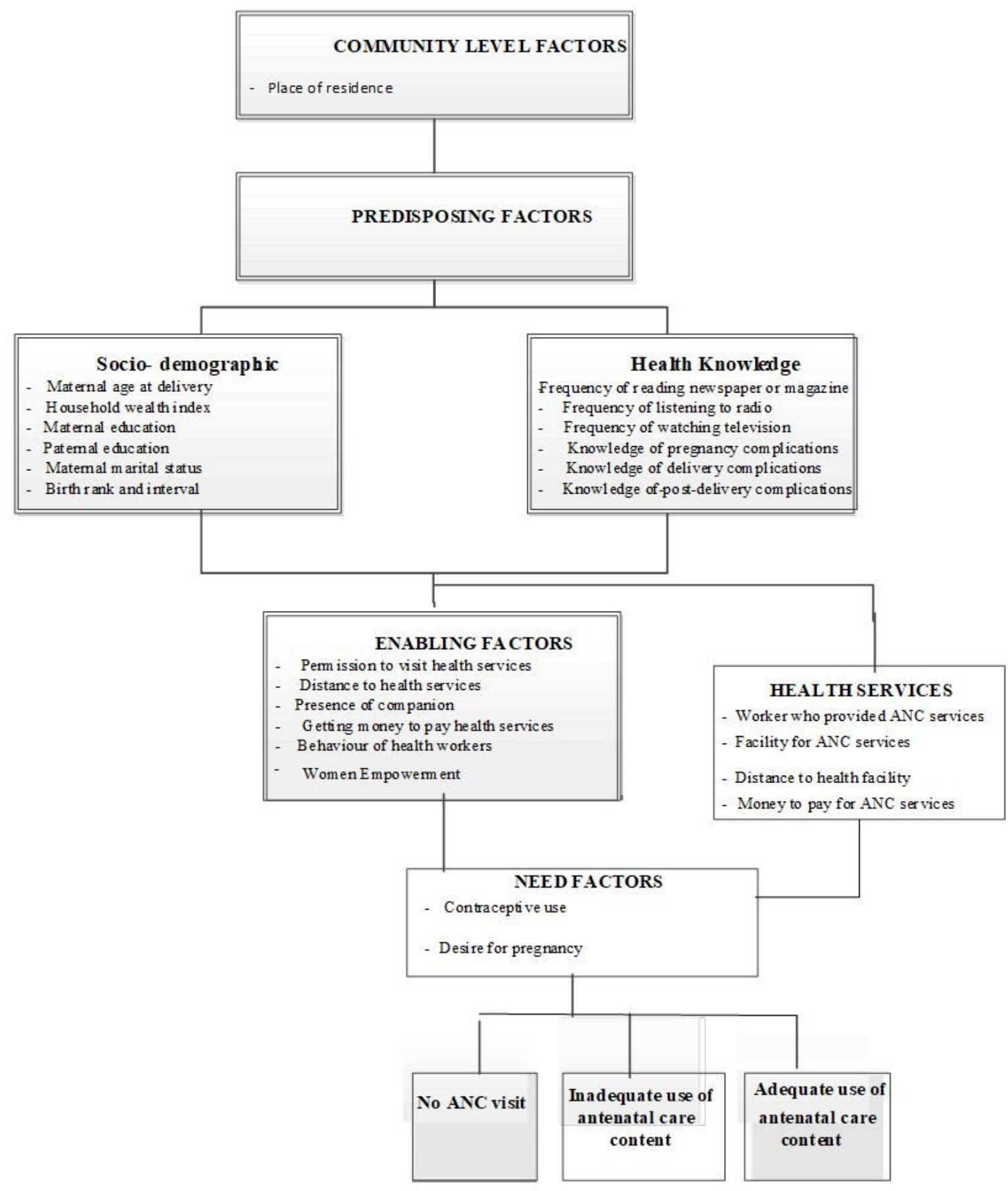

Figure 1

Conceptual framework adapted from Anderson behavioural model 


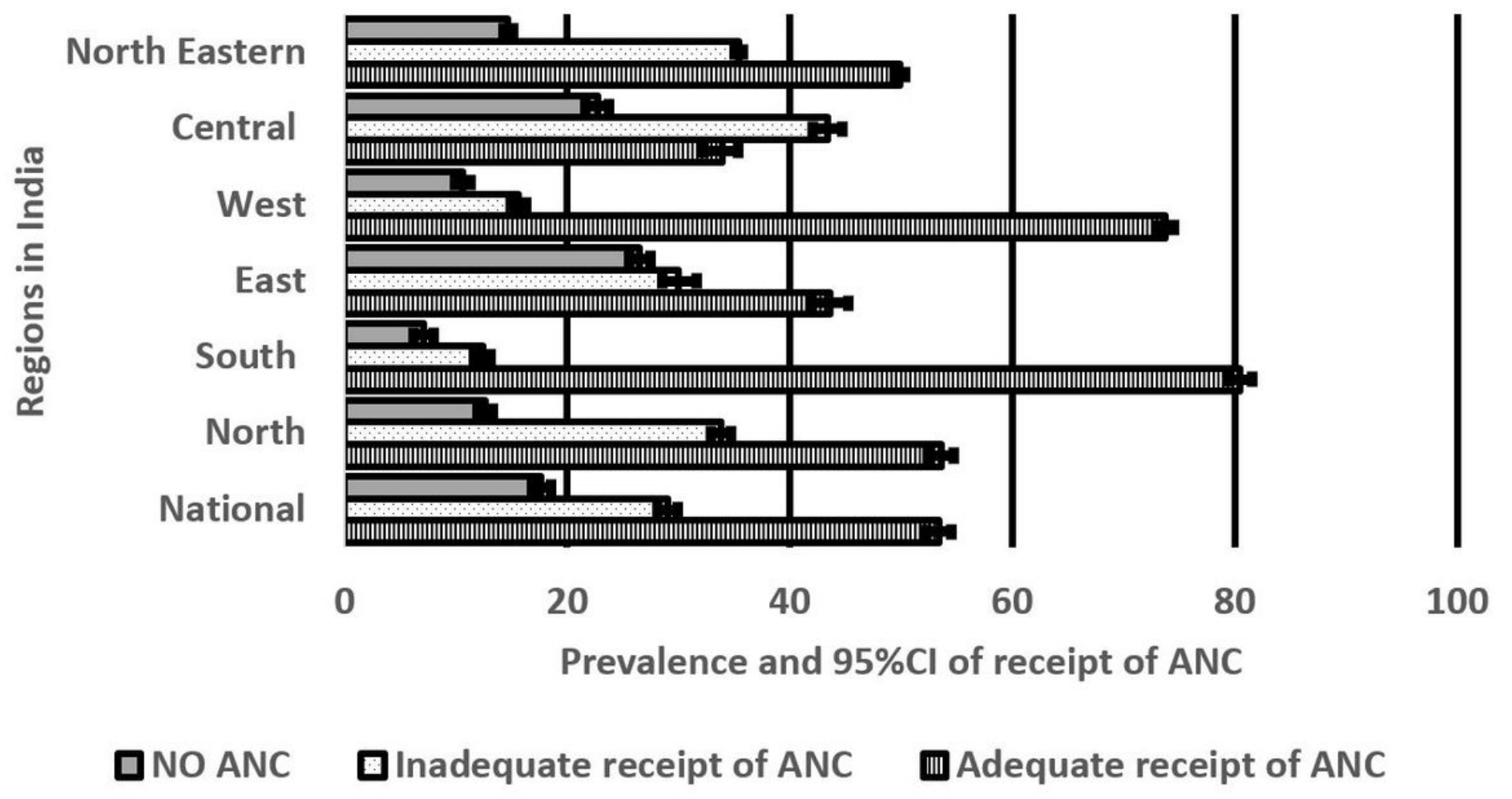

Figure 2

Regional prevalence and $95 \% \mathrm{Cl}$ of no, inadequate and adequate receipt of the components of ANC visits, NFSH-4. 